\title{
Levels of Norovirus and $E$. coli in Untreated, Biologically Treated and UV-Disinfected Sewage Effluent Discharged to a Shellfish Water
}

\author{
Carlos J. A. Campos ${ }^{1}$, Justin Avant ${ }^{1}$, James Lowther ${ }^{1}$, Dale Till ${ }^{2}$, David Lees ${ }^{1}$ \\ ${ }^{1}$ Aquatic Health \& Hygiene Division, Centre for Environment, Fisheries \& Aquaculture Science (CEFAS), \\ Weymouth Laboratory, Weymouth, UK \\ ${ }^{2}$ Southern Water, Chichester, UK \\ Email: carlos.campos@cefas.co.uk
}

Received July 30, 2013; revised September 2, 2013; accepted September 28, 2013

Copyright (C) 2013 Carlos J. A. Campos et al. This is an open access article distributed under the Creative Commons Attribution License, which permits unrestricted use, distribution, and reproduction in any medium, provided the original work is properly cited.

\begin{abstract}
The efficacy of an activated sludge (modified Ludzack-Ettinger (MLE)) UV disinfection processes in removing human noroviruses and E. coli from sewage were compared with the prevalence of these microorganisms in a settled storm discharge from the same sewage treatment works. Both discharges impacted a designated oyster production area. The treatment process delivered average $\mathrm{NoV}$ and $E$. coli reductions of $2.9 \log _{10}$ and $5.2 \log _{10}$, respectively. Most E. coli reductions occurred during the UV disinfection process whereas the MLE process was comparatively more important in reducing NoV levels. A positive relationship was found between NoV removal and measured applied UV dose. The average levels of total NoV in the settled storm tank were of the same order of magnitude of those in screened raw influent at the works. These results highlight the importance of measures to reduce the impact of stormwater discharges to minimise the risk of NoV gastroenteritis associated with the consumption of oysters.
\end{abstract}

Keywords: Activated Sludge; E. coli; Norovirus; Sewage; Stormwater; UV Disinfection

\section{Introduction}

Raw sewage contains large numbers of viruses, many of which can cause illness in humans through ingestion of faecally contaminated water or food [1]. Filter-feeding bivalve shellfish are efficient vehicles for the transmission of viruses to humans via the faecal-oral route [2]. Currently there is evidence that most outbreaks of acute non-bacterial gastroenteritis associated with the consumption of shellfish in the developed world are due to human noroviruses (NoV) [2,3].

Over recent decades, water companies in England and Wales (E\&W) have made substantial investments in sewerage plants and infrastructure to improve the quality of shellfish growing waters. These have been prompted by the implementation of various European statutory requirements namely the Urban Wastewater Treatment Directive, the Bathing Waters Directive, and the Shellfish Waters Directive. In general these have resulted in the implementation of land-based secondary (biological) treatment often followed by ultraviolet (UV) disinfection for discharges impacting shellfish waters [4]. These dis- charges are regulated through consent conditions concerning the operational performance of the plant, performance of the disinfection process such as UV dose and microbiological efficacy monitoring programmes [5].

A significant proportion of the sewerage network in $\mathrm{E} \& \mathrm{~W}$ is still comprised of combined sewer systems that transport surface water and foul (sewage and trade) effluent flows in one pipe. These systems include three types of intermittent discharges: combined sewer overflows (CSOs) at sewage treatment works (STWs) and on the sewerage network; storm tank overflows (STOs) also at STWs and on the sewerage network; and emergency overflows from pumping stations. Storm tanks normally deal with the polluting "first flush" of storm sewage and are particularly important where the microbiological quality of the receiving waters may require protection. The consenting policy for these types of discharges is to reduce their impact through controlling the volume and frequency of spills. For CSOs and STOs impacting shellfish waters, the minimum design criteria required by the 
consenting authority is that the frequency of significant spills should not exceed 10 per annum on average (over 10 years) [6].

It has long been recognised that activated sludge and UV disinfection could be effective in removing viruses from sewage [7]. However, to date few studies have investigated the efficacy of these forms of treatment in removing NoV from sewage and even less information is available on typical levels of these viruses in intermittent discharges (e.g. CSOs and STOs). To characterise the relative NoV risk from untreated, biologically treated and UV disinfected sewage discharges impacting an oyster production area, we quantified levels of E. coli and NoV in settled storm sewage and investigated the efficacy of activated sludge/modified Ludzack-Ettinger (MLE) and UV disinfection in removing NoV and E. coli from sewage in a fully operational STWs discharging to a commercial fishery.

\section{Methods}

\subsection{Sewage Treatment Works}

The STW serves a population equivalent of approximately 34,832 . The discharge consent conditions determine that the volume of treated effluent under dry weather conditions must not exceed $13,524 \mathrm{~m}^{3}$ in any period of $24 \mathrm{~h}$. The volume of settled storm sewage discharged to the shellfish water shall be limited to that resulting from the overflow of sewage at the works' inlet storm overflow of flows in excess of $300 \mathrm{l} / \mathrm{s}$. All crude sewage is screened via $6 \mathrm{~mm}$ screens and de-gritted via a detritor. The treatment of full flow to treatment consists of two circular primary tanks and anoxic and aeration zones with four final settlement tanks. The plant operates a MLE activated sludge process which is a two-stage biological nitrification/de-nitrification process with internal recirculation. The $\mathrm{N}$ removal process consists of an aerobic zone in which nitrification occurs and an anaerobic zone in which de-nitrification occurs. The nitrified flow is fed back to the low oxygen anoxic zones, which is de-nitrified by the influent flow from the primary settlement tanks. The treatment process also includes a packaged ultraviolet (UV) disinfection plant consisting of UV modules mounted in parallel units grouted into concrete channels. The plant is fitted with a telemetry alarm system connected to a $24 \mathrm{~h}$ manned station to provide warning in case of interruption in external power supply, failure to control UV dosing system or discharged effluent not subjected to the required UV dosing system. Both the MLE system and the UV plant were installed and the capacity of the storm tank increased as part of a programme of sewerage infrastructure improvements at this plant in 2008 .

\subsection{Collection of Sewage Samples}

Nine sampling campaigns were undertaken during the period October 2012-March 2013. Sewage samples representative of five stages of the treatment process (Figure 1) were always collected in the morning by dip sampling (by filling the container just beneath the surface of the effluent). Screened influent samples were collected from a sampling point immediately downstream of screening and grit removal. Final effluent samples were collected from the designated compliance monitoring point. Samples $(250 \mathrm{ml})$ were collected in duplicate and transported in cool boxes to the Laboratory on the day of sampling. All samples were processed within $12 \mathrm{~h}$ of collection and stored at $4^{\circ} \mathrm{C}$.

\subsection{Quantification of Norovirus}

\subsubsection{Concentration of Norovirus}

The preparation of wastewater concentrates followed the procedure developed by Cross (2004) [8] as modified from Puig et al. (1994) [9].

\subsubsection{Purification of Viral RNA and RT-PCR}

The procedures to extract viral RNA and determine qRTPCR controls and quantification were as described by Lowther et al. (2012) [10]. Results were recorded as genome copies $/ \mathrm{ml}$.

\subsection{Quantification of $E$. coli}

Levels of $E$. coli were quantified using a modified membrane filtration technique that uses membrane lauryl sulphate broth as recovery medium [11]. Results were recorded as CFU/100 ml.

\subsection{Sewage Treatment Works' Operational Performance}

Compliance monitoring of levels of faecal coliforms in the final effluent post UV disinfection for the period July 2008-June 2011 were supplied by the water company. Additional information on sewage spill frequency and duration, flows, estimated sewage residence time and measured applied UV dose for the plant was provided by the water company. The applied UV dose is a theoretical calculation based on the type of lamp, lamp/channel configuration and the assumed UV transmissivity of the effluent. Many discharge consents in E\&W are based on

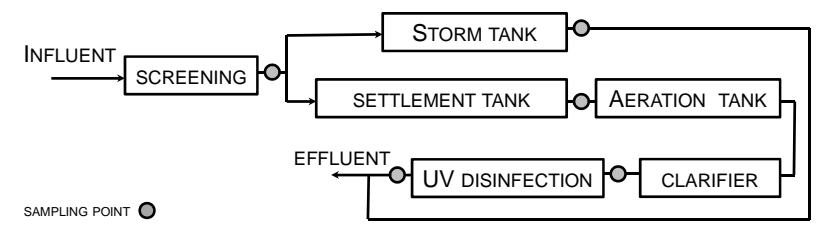

Figure 1. Schematic of sampling points. 
either the received dose or applied dose. However, it is generally accepted that measured applied dose is more informative because transmissivity is more easily and more accurately measured than UV intensity [5]. Consent conditions for these STWs determine that the measured applied UV dose must exceed $32 \mathrm{~mJ} / \mathrm{cm}^{2}$ for at least $99 \%$ of the measurements in any period of 12 consecutive months.

\subsection{Statistical Analyses}

All statistical analyses were performed in Minitab 16. Samples returning results of "not detected for GI or GII were assigned a value of zero. Because of the logarithmic relationship of microbial inactivation versus UV dose, the NoV/E. coli removal rates were calculated as follows:

$$
\log _{10} \text { removal rate }=\log _{10} \mathrm{Ns} / \mathrm{Ni}
$$

where:

Ns - concentration of surviving organisms; and

$\mathrm{Ni}$-initial concentration of organisms before exposure.

\section{Results}

Geometric mean levels of faecal coliforms in the final effluent since the installation of the UV plant were 87 $\mathrm{CFU} / 100 \mathrm{ml}$.

Levels of NoV (GI and GII) in sewage (all stages of the treatment process combined) during the period October 2012-March 2013 were significantly (Ryan-Joiner test; $p<0.010)$ skewed. When $\log _{10}$-transformed, these data remained with both sides of the distribution heavier than expected for the normal distribution curve. This skewed distribution is typically detected in microorganisms in association with different sewage matrices (e.g. bulk water, biofilms, particles/aggregated).

Noroviruses were consistently detected in raw sewage during the study period. Overall, on an individual sample basis GI was less prevalent than GII. In fact, all influent and settled storm samples were positive for NoV GII.

Total NoV (GI plus GII combined) level generally increased with residence time of the sewage in the storm tank (Figure 2).

The concentrations of E. coli and NoV across the stages of sewage treatment during the study period are shown in Table 1. Geometric mean levels of GI were consistently lower than those of GII across all stages of the sewage treatment process.

The percentages of positive samples for GI and GII at the end of the secondary treatment process (activated sludge post-clarifiers) were $50 \%$ and $100 \%$, respectively. Maximum levels of GI and GII in influent and settled storm samples was relatively similar $\left(\approx 1 \log _{10}\right)$.

The telemetry alarm fitted to the storm tank overflow at the works recorded 167 sewage spill events (duration =

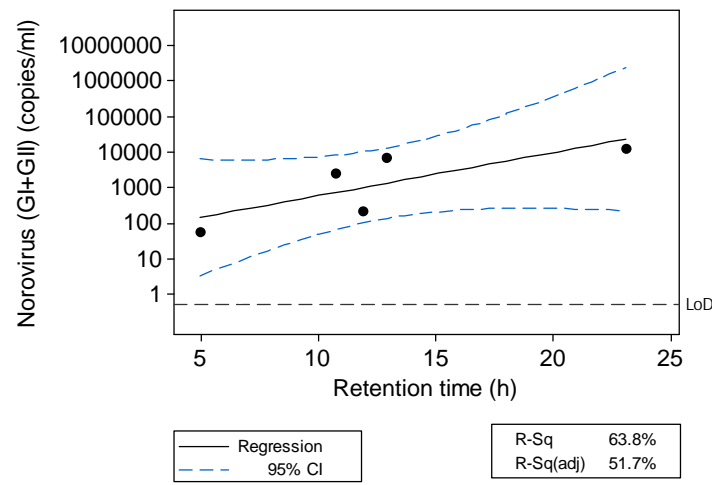

Figure 2. Relationship between total norovirus and retention time in the storm tank. Linear model: $\log _{10}$ norovirus (GII) $($ copies $/ \mathrm{ml})=(1.552-0.1217) *$ retention time $(\mathrm{h}) ; \mathbf{R}^{2}$ $=63.8 \%$.

4 - 54,489 min) during the study period. Importantly, the total NoV levels in the settled storm sewage samples were of the same order of magnitude of those in the raw influent on most sampling occasions. Using measured flow data, it was estimated that NoV loadings (copies/day) for the storm tank ranged from $9 \times 10^{9}$ to $2 \times$ $10^{11}$. Under similar weather conditions, the loadings from the storm tank were $1-3$ orders of magnitude higher than those from the UV-disinfected effluent and represented $97.6 \%-99.9 \%$ of the total NoV loading from the STW.

$\mathrm{NoV}$ and $E$. coli reductions seen across the treatment works varied significantly between sampling occasions. Overall, the STW delivered average reductions of 5.2 $\log _{10}$ and $2.9 \log _{10}$ for E. coli and total NoV, respectively (Table 2).

Most E. coli reductions occurred during UV disinfection whereas most total NoV reductions occurred during the activated sludge process although differences were observed between removal rates for NoV GI and GII. All NoV concentrations in the final discharged effluent samples were $<100$ genome copies $/ \mathrm{ml}$.

NoV concentrations in the final effluent were found to correlate with measured applied UV dose received by the effluent (Figure 3).

The applied dose levels were all above $32 \mathrm{~mJ} / \mathrm{cm}^{2}$ and therefore in conformity with the limit set out in the consenting conditions for this plant.

\section{Discussion}

This research aimed to assess the efficacy of a modern sewage treatment plant with UV disinfection for removal of NoV, and to compare this with the NoV risk from settled storm sewage overflows at the same works. The levels of faecal coliforms and E. coli found in the final effluent are consistent with those detected in a selection of STWs across the UK under high flow conditions [12]. The sampling programme designed for this study showed 
Table 1. Summary of levels of $E$. coli and norovirus in sewage samples.

\begin{tabular}{|c|c|c|c|c|c|c|c|c|c|c|c|c|}
\hline & \multicolumn{3}{|c|}{ E. coli (CFU/100ml) } & \multicolumn{3}{|c|}{ Norovirus (GI) (copies/ml) } & \multicolumn{3}{|c|}{ Norovirus (GII) (copies/ml) } & \multicolumn{3}{|c|}{ Norovirus (GI + GII) (copies/ml) } \\
\hline Treatment level & 䒠 & 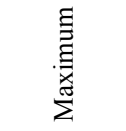 & $\begin{array}{l}\stackrel{0}{\Xi} \\
\stackrel{\Xi}{\Xi} \\
\stackrel{\Xi}{\Xi} \\
\stackrel{\Xi}{\Xi} \\
\stackrel{\Xi}{E}\end{array}$ & 声 & 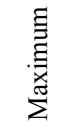 & 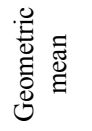 & 声 & 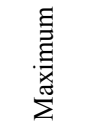 & 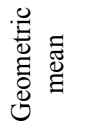 & 害 & 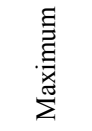 & $\begin{array}{l}\stackrel{0}{\Xi} \\
\stackrel{\Xi}{\Xi} \\
\stackrel{\Xi}{\Xi} \\
\stackrel{\Xi}{\Xi} \\
\stackrel{\Xi}{\Xi}\end{array}$ \\
\hline Influent (screened) & $1,800,000$ & $9,600,000$ & $4,079,170$ & 8 & 1094 & 152 & 398 & 73,536 & 4903 & 398 & 73,536 & 4903 \\
\hline Settled storm tank & 975,000 & $2,400,000$ & $1,410,801$ & 12 & 575 & 79 & 59 & 13,034 & 1645 & 59 & 13,201 & 1690 \\
\hline $\begin{array}{l}\text { Activated sludge } \\
\text { (settlement tank) }\end{array}$ & 7800 & 29,700 & 16,002 & 3 & 1354 & 37 & 5 & 2922 & 105 & 5 & 3033 & 114 \\
\hline $\begin{array}{l}\text { Activated sludge } \\
\text { (post-clarifiers) }\end{array}$ & 6500 & 21,600 & 11,859 & 1 & 2 & 2 & 4 & 164 & 17 & 4 & 166 & 17 \\
\hline $\begin{array}{c}\text { Effluent } \\
\text { (UV-disinfected) }\end{array}$ & 6 & 198 & 25 & 1 & 6 & 2 & 5 & 37 & 15 & 5 & 43 & 16 \\
\hline
\end{tabular}

Table 2. Removal and $E$. coli and norovirus through the sewage treatment process.

\begin{tabular}{ccccccc}
\hline & \multicolumn{5}{c}{ Sewage treatment stage } \\
\cline { 2 - 7 } Microorganism & $\begin{array}{c}\text { Influent-settled } \\
\text { storm }\end{array}$ & $\begin{array}{c}\text { Influent-activated } \\
\text { sludge } \\
\text { (settlement tank) }\end{array}$ & $\begin{array}{c}\text { Activated sludge } \\
\text { (settlement tank)- } \\
\text { activated sludge } \\
\text { (post clarifiers) }\end{array}$ & $\begin{array}{c}\text { Activated sludge } \\
\text { (post clarifiers)- } \\
\text { ultraviolet disinfection }\end{array}$ & $\begin{array}{c}\text { Influent-activated } \\
\text { sludge } \\
\text { (post-clarifiers) }\end{array}$ & $\begin{array}{c}\text { Influent-ultraviolet } \\
\text { disinfection }\end{array}$ \\
$\begin{array}{c}\text { E. coli } \\
(\text { CFU/100ml) }\end{array}$ & 0.32 & 2.41 & 0.13 & 2.67 & 2.54 & 5.21 \\
$\begin{array}{c}\text { Norovirus }(\mathrm{GI}) \\
\text { (copies/ml) }\end{array}$ & 0.47 & 0.69 & 1.00 & $\begin{array}{c}\text { Insufficient number of } \\
\text { samples }\end{array}$ & 2.13 & 2.08 \\
$\begin{array}{c}\text { Norovirus }(\mathrm{GII}) \\
\text { (copies/ml) }\end{array}$ & 0.28 & 1.65 & 0.80 & 0.13 & 2.63 & 2.94 \\
$\begin{array}{c}\text { Norovirus }(\mathrm{GI}+\mathrm{GII}) \\
\text { (copies/ml) }\end{array}$ & 0.29 & 1.84 & 0.51 & 0.11 & 2.64 & 2.92 \\
\hline
\end{tabular}

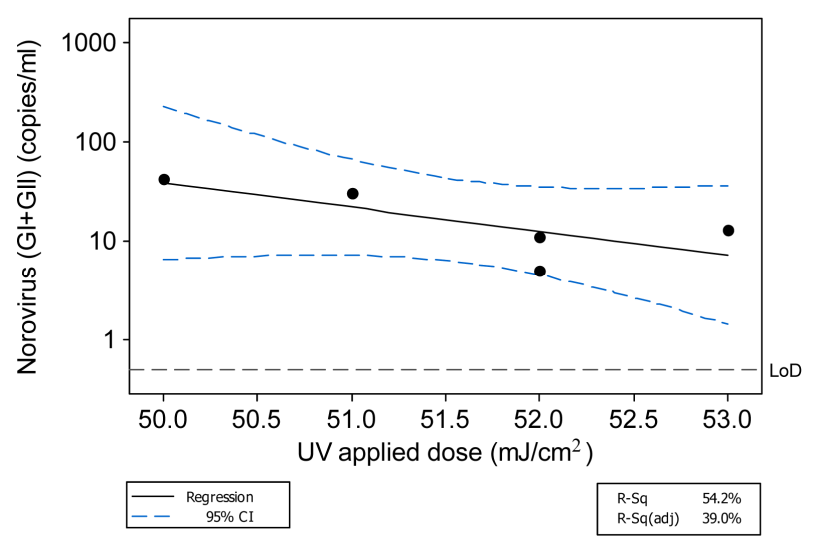

Figure 3. Relationship between norovirus removal and applied UV dose. Linear model: $\log _{10}$ norovirus (GI + GII) $($ copies $/ \mathrm{ml})=(13.63-0.2409) * \mathrm{UV}$ applied dose $\left(\mathrm{mJ} / \mathrm{cm}^{2}\right)$; $\mathbf{R}^{2}=54.2 \%$.

that most E. coli reductions occur during UV disinfection with average reductions characteristics of the better performing plants in E\&W [4]. The E. coli removal rates detected from influent to the final stage of the secondary treatment process are higher than those detected before the sewerage improvements $\left(2.5 \log _{10}\right)$ when the plant was operating $20 \%$ conventional activated sludge and $80 \%$ trickling filters [8]. This suggests that activated sludge is more effective than trickling filters for $E$. coli removal.

Norovirus was consistently present in both raw and treated sewage during the study period. This period is typically associated with high NoV prevalence in the community and included the oyster harvest season in the studied shellfish water. Thus there was clearly a potential NoV contamination risk for discharged effluent impacting the oyster production areas. However, a limitation of molecular based studies is the lack of information on the effect of UV disinfection on NoV infectivity. In this regard, it was interesting to note the relationship of NoV titre in final effluents to the applied UV dose. The large differences detected in NoV titre over the relatively small differences in applied UV dose suggest that this parameter is critically important in terms of effectiveness of NoV removal and that higher doses will significantly assist NoV reduction during treatment. The mechanism for this is not clear and further research and corroboration would be beneficial.

Pathogen removal by activated sludge has been reported to be highly variable depending on the type of 
organism and performance of the plant [13]. The results indicate that the MLE activated sludge process involving a two-stage biological nitrification/de-nitrification process is reasonably effective in removing NoV from sewage $(2.6 \operatorname{logs})$. The removal rates for total NoV during activated sludge processes are similar to those found in a selection of STWs in the UK [14].

The finding of most public health relevance in this study is that STO discharges clearly represented the main risk of NoV contamination of the shellfish water. NoV concentrations were similar in raw untreated influent and in settled storm samples. The significance of this continuous flux of NoV to the commercial oyster beds is being subject to further investigations.

Planned mitigation strategies include the treatment of the stormwater discharge with UV disinfection. However, it will be important to ensure that this is effective for NoV control. The positive association between total NoV levels and retention time in the storm tank should be further explored since it opens the possibility of using additional treatments such as waste stabilization ponds to promote sedimentation and increase hydraulic retention times in catchment areas associated with high NoV fluxes.

This study shows that NoV analysis can give important information of the performance of STWs for control of this pathogen prior to environmental discharge. Further studies are warranted to investigate a wider range of treatment plants and biological variables.

\section{Acknowledgements}

We are grateful to Paul Linwood (Southern Water) for technical inputs and Ian Udal for supplying final effluent faecal coliform data. This study was funded by the Department for Environment, Food and Rural Affairs (SEPF WT0996, "Contamination of shellfish waters with human noroviruses: environmental risk factors and management options").

\section{REFERENCES}

[1] P. G. Cantalupo, B. Calgua, G. Zhao, A. Hundesa, A. D. Wier, J. P. Katz, M. Grabe, R. W. Hendrix, R. Girones, D. Wang and J. M. Pipas, "Raw Sewage Harbors Diverse Viral Populations," mBio, Vol. 2, No. 5, pp. e00180-11.

[2] D. Lees, "Viruses and Bivalve Shellfish," International Journal of Food Microbiology, Vol. 59, No. 1-2, 2000, pp. 81-116. http://dx.doi.org/10.1016/S0168-1605(00)00248-8

[3] C. T. Zainazor, M. S. Noor Hidayah, L. C. Chai, R. Tunung, F. M. Ghazali and R. Son, "The Scenario of No- rovirus Contamination in Food and Food Handlers," Journal of Microbiology and Biotechnology, Vol. 20, No. 2, 2010, pp. 229-237.

[4] Environment Agency, "Efficacy and Effects of Wastewater Disinfection Phase 5 Review of Wastewater UV Disinfection Performance in England and Wales," Environment Agency R\&D Technical Report P2-036/TR, 2002.

[5] Environment Agency, "Water Discharge Permitting: Disinfection of Wastewater," Operational Instruction 347_09 Issued 30/06/2010.

[6] Environment Agency, "Consenting Guidance to Achieve the requirements of the Shellfish Waters Directive (Microbial Quality)," Environment Agency Water Quality Consenting Guidance 169_01 Issued 30/01/2003.

[7] G. Berg, "Removal of Viruses from Sewage, Effluents, and Waters. 1. A Review," Bulletin of the World Health Organization, Vol. 49, No. 5, 1973, pp. 451-460.

[8] L. J. Cross, "The Development and Application of Quantitative Methods for Norovirus Detection in Sewage Effluents and Seawater," Ph.D. Thesis, School of Biomedical \& Molecular Sciences, University of Surrey, Guildford, 2004

[9] M. Puig, J. Jofre, F. Lucena, A. Allard, G. Wadell and R. Girones, "Detection of Adenoviruses and Enteroviruses in Polluted Waters by Nested PCR Amplification," Applied and Environmental Microbiology, Vol. 60, No. 8, 1994, pp. 2963-2970.

[10] J. A. Lowther, N. E. Gustar, A. L. Powell, R. E. Hartnell and D. N. Lees, "Two-Year Systematic Study to Assess Norovirus Contamination in Oysters from Commercial Harvesting Areas in the United Kingdom," Applied and Environmental Microbiology, Vol. 78, No. 16, 2012, pp. 5812-5817. http://dx.doi.org/10.1128/AEM.01046-12

[11] Environment Agency, "The Microbiology of Recreational and Environmental Waters. Methods for the Examination of Waters and Associated Materials," Environment Agency, Bristol, 2000.

[12] D. Kay, J. Crowther, C. M. Stapleton, M. D. Wyer, L. Fewtrell, A. Edwards, C. A. Francis, A. T. McDonald, J. Watkins and J. Wilkinson, "Faecal Indicator Organism Concentrations in Sewage and Treated Effluents," Water Research, Vol. 42, No. 1-2, 2008, pp. 442-454. http://dx.doi.org/10.1016/i.watres.2007.07.036

[13] C. P. Gerba, "Pathogen Removal," In: M. Henze, M. C. M. van Loosdrecht, G. A. Ekama and D. Brdjanovic, Eds., Biological Wastewater Treatment: Principles, Modelling and Design, IWA Publishing, Cambridge University Press, London, 2008, pp. 221-242.

[14] R. Palfrey, M. Harman and R. Moore, "Impact of Waste Water Treatments on Removal of Noroviruses from Sewage," WRc R\&D Technical Report WT0924/TR to Defra, 2011. 